\title{
Canopy replacement used in the evaluation of cupuassu tree genotypes in the state of Pará
}

\author{
Rafael Moysés Alves ${ }^{1}$, Saulo Fabrício da Silva Chaves $^{2}$, Raimundo Parente de Oliveira ${ }^{3}$, \\ Jack Loureiro Pedroza Neto ${ }^{4}$, Alexandre Sebbenn ${ }^{5}$
}

\begin{abstract}
This study aimed to use the canopy replacement technique to reduce the field evaluation time and to select promising cupuassu tree clones. The study was carried out under field conditions using fifteen-year-old trees. The crowns were replaced using 16 treatments (clones). The experiment was conducted using randomized blocks design with 18 replicates and one plant per plot, during a period of ten years. The following variables were evaluated: average number of fruits, fruit, seed and pulp production (kg/plant) and symptoms of "witches broom" disease. The data were checked for normality followed by analysis of variance. The results highlighted clones 32, 42, 44, 46, 47, 61, 62, 63 and 64, presenting characteristics such as productivity, tolerance to witches' broom disease and interesting fruit characteristics. The results demonstrate that the technique was effective in the evaluation of cupuassu tree genotypes, since the clones revealed their potential at early stages after establishment in the field. There was a reduction by at least $30 \%$ regarding the time needed to evaluate cupuaçu tree genotypes. Five clones $(32,42,46,61$ and 64$)$ already present the potential to be made available to producers, aimed at replacing the canopy of unproductive trees.
\end{abstract}

Index terms: Theobroma grandiflorum; genetic breeding; clone selection; over grafting; witch's broom.

\section{A substituição de copa empregada para avaliação de genótipos de cupuaçuzeiro, no Estado do Pará}

Corresponding author: rafael-moyses.alves@embrapa.br

Received: February 13, 2020 Accepted: April 27, 2020

Copyright: All the contents of this journal, except where otherwise noted, is licensed under a Creative Commons Attribution License.

\begin{abstract}
Resumo - O objetivo deste trabalho foi utilizar a técnica de substituição de copa para tentar reduzir o tempo de avaliação em campo e selecionar clones promissores de cupuaçuzeiro. Árvores de 15 anos de idade no campo tiveram suas copas substituídas e 16 tratamentos (clones) foram utilizados em um delineamento de blocos casualizados com 18 repetições e uma planta por parcela. O experimento durou 10 anos e foram avaliados o número médio de frutos, produção de frutos, sementes e polpa (kg/planta) e os sintomas da doença "vassoura-de-bruxa". Os dados obtidos foram submetidos ao teste de normalidade e, posteriormente, à ANOVA. Os resultados destacaram os clones 32, 42, 44, 46, 47, 61, 62, 63 e 64, reunindo, entre eles, indivíduos com características como produtividade, tolerância à vassoura-de-bruxa e características interessantes de frutos. Os desempenhos demonstram que a técnica foi eficaz na avaliação de genótipos de cupuaçuzeiro, uma vez que os clones revelaram seu potencial, desde os primeiros anos de estabelecimento em campo. Isso permitiu reduzir em pelo menos $30 \%$ o tempo necessário para avaliar o genótipo da árvore de cupuaçu. Dos nove clones apresentados, cinco clones $(32,42,46,61$ e 64) já devem estar disponíveis aos produtores para substituir o dossel de árvores improdutivas.

Termos para indexação: Theobroma grandiflorum; melhoramento genético; seleção clonal; sobre-enxertia; vassoura de bruxa.
\end{abstract}

\footnotetext{
${ }^{1}$ Agronomist, Doctor in Genetics and plant breeding, researcher in Empresa Brasileira de Pesquisa Agropecuária, Amazônia Oriental unit, Belém-Pará, Brasil. E-mail: rafael-moyses.alves@embrapa.br (ORCID: 0000-0002-9826-4690).

${ }^{2}$ Agronomist, mastering in Genetics and plant breeding, Universidade Federal de Viçosa, Viçosa-MG, Brasil. E-mail:saulofabricioagro@gmail. Com (ORCID: 0000-0002-0694-1798)

${ }^{3}$ Agronomist, Master in Statistics and Quantitative Methods, biostatistics analyst in Empresa Brasileira de Pesquisa Agropecuária, Amazônia Oriental unit FALTANDO CIDADE, ESTADO ORCID... E-mail: raimundo.parente@embrapa.br.

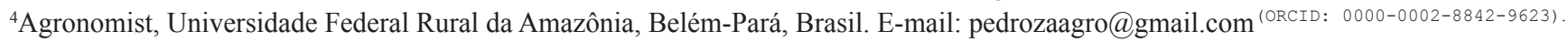

${ }^{5}$ Forest engineer, Doctor in Genetics and plant breeding, researcher in Instituto Florestal de São Paulo, São Paulo-SP, Brasil. E-mail: alexandresebbenn@yahoo.com.br (ORCID 0000-0003-2352-0941)
} 


\section{Introduction}

Cupuassu trees [Theobroma grandiflorum (Willd. Ex Spreng.) Schum.], which belongs to the Malvaceae family and the Sterculioideae subfamily, is a fruit specie of great commercial value (CHASE et al., 2016). The acid pulp of the fruits, which presents an intense aroma and flavor, is the main product of cupuassu for the production of juices, jellies, sweets and ice cream, among other products (GONÇALVES et al., 2010; BORGES et al., 2017). The seeds of cupuassu have been used in the cosmetics and pharmaceutical industry. Cupuassu seeds can be made into cupulate, which looks and tastes just like chocolate but is cheaper and more resistant to heat. The cupuassu almond liqueur has characteristics superior to that of cocoa, presenting higher antioxidant properties and a lower percentage of saturated fatty acids (OLIVEIRA; GENOVESE, 2013). The tree bark can be used for energy production (SANTOS et al., 2004), as well as handicrafts and organic fertilizers. As for fruits, they vary in shape, length, size and weight. This variation is used in breeding programs for the different uses of fruits and their derivatives (seeds, pulp, peel, liquor, etc.).

The species can be multiplied sexually (seeds) or asexually (vegetative). Grafting is a vegetative and asexual plant propagation technique widely used to provide resistance to biotic adversities such as pathogens, or abiotics such as water, climatic and salinity stresses (FERNANDES et al., 2011; SIRTOLI et al., 2011; SILVA et al., 2012). As a result, it provides the formation of uniform orchards with homogeneous populations (FRANZON et al., 2010). The technique can also influence the vegetative development, as well as the phenology and productivity of the cultivar (COMIOTTO et al., 2012) conserving desirable characteristics of the genotype of the grafted plant (SANTOS et al., 2010).
As a part of cupuassu breeding programs, there is a need to evaluate and release genotypes with the characteristics desirable by the producers. However, cupuassu tree is a perennial species with a breeding cycle of not less than 15 years. Therefore, there is a need to develop a reliable methodology that allows the selection of cupuassu tree genotypes with maximum brevity without compromising the selection efficiency. Grafting has recently been used to replace the canopy of unproductive cupuassu tress, especially those affected by the Witches'-broom disease (ALVES, 2014). The technique consists in replacing the original canopy for a productive cupuassu tree clone that is resistant to this disease. It is an option for producers who have orchards that have aged, are unproductive and/ or susceptible to diseases that affect cupuassu tress. The main advantage of the technique is the rapid recovery of the productivity of the orchard, which might double or even triple the original productivity depending on the clones and appropriate treatments (ALVES, 2014).

Therefore, this study aimed to use the canopy replacement technique to reduce the genetic breeding cycle of cupuassu tress and to select genotypes already adapted to this technology to be recommended to producers or to be incorporated into breeding programs.

\section{Material and methods}

The experiment was conducted at the Physical Base of Embrapa Amazônia Oriental, from 2007 to 2017, in Tomé Açu, state of Pará, Brazil $\left(02^{\circ} 26^{\prime} 08^{\prime \prime} \mathrm{S}\right.$ and $\left.48^{\circ} 09^{\prime} 08^{\prime \prime} \mathrm{W}\right)$. The soil is classified as Yellow Latosol with medium texture. According to the Köppen classification, the climate is mesothermal and humid (Ami type) (BOLFE; BATISTELLA, 2011). The region presents air relative humidity of around $85 \%$, average annual precipitation of $2,300 \mathrm{~mm}$ and average temperature of $26^{\circ} \mathrm{C}$. The results of precipitation and relative humidity during the experimental period are shown in Figure 1.

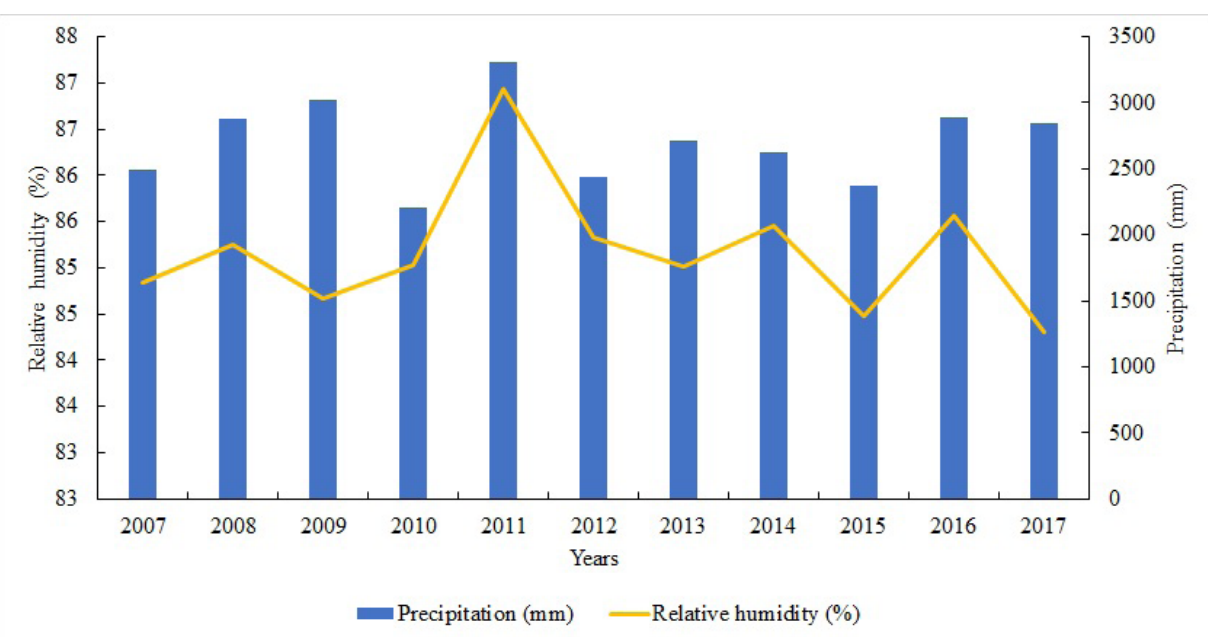

Figure 1. Precipitation and average relative humidity during the years of evaluation of cupuaçu tree clones, ToméAçu, Pará State, Brazil. 
A total of 16 cupuaçu tree genotypes (clones) were evaluated (Table 1). The canopy replacement technique was used, according to Alves (2014). Clones 174, 215 and 1074 were commercial witnesses. The first two were released by
Embrapa Amazônia Oriental in 2012, BRS Coari (174) and BRS Manacapuru (215). Clone 1074 is a primary material widely used in breeding programs related to cupuassu.

Table 1. Cupuaçu tree clones and their respective ancestry and origin, in Tomé-Açu, Pará State, Brazil.

\begin{tabular}{|c|c|c|c|}
\hline Clone & Ancestrally & Mother origin location & Father origin location \\
\hline 32 & $174 \times 186$ & 174: Coari-AM & 186: Codajás - AM \\
\hline 42 & $186 \times 434$ & 186: Codajás - AM & 434: Muaná - PA \\
\hline 44 & $186 \times 434$ & 186: Codajás - AM & 434: Muaná - PA \\
\hline 46 & $186 \times 215$ & 186: Codajás - AM & 215: Manacapuru - AM \\
\hline 47 & $186 \times 1074$ & 186: Codajás - AM & 1074: Itacoatiara - AM \\
\hline 48 & $186 \times 1074$ & 186: Codajás - AM & 1074: Itacoatiara - AM \\
\hline 51 & $215 \times 624$ & 215: Manacapuru - AM & 624: Santarém - PA \\
\hline 56 & $186 \times 1074$ & 186: Codajás - AM & 1074: Itacoatiara - AM \\
\hline 57 & $186 \times 513$ & 186: Codajás - AM & 513: Oiapoque - AP \\
\hline 61 & $220 \times 228$ & 220: Manacapuru - AM & 228: Manaus - AM \\
\hline 62 & $220 \times 185$ & 220: Manacapuru - AM & 185: Codajás - AM \\
\hline 63 & $174 \times 248$ & 174: Coari-AM & 248: Itacoatiara - AM \\
\hline 64 & $220 \times 185$ & 220: Manacapuru - AM & 185: Codajás - AM \\
\hline 1074 & Primary & 1074: Parintins - AM & - \\
\hline 174 & Primary & 174: Coari -AM & - \\
\hline 215 & Primary & 215: Manacapuru - AM & - \\
\hline
\end{tabular}

For the installation of the experiment, adult plants were grafted, using the technique of canopy replacement or over grafting. In each plant, one to three grafts were made with a single clone (Figure 2). The preparation of the area consisted of a mechanical rubbing between the lines. Fifteen-year-old cupuassu trees were spaced at $6 \times 5$ $\mathrm{m}$ with a density of 333 plants per hectare in full sun. The branches with witch broom attack (Moniliophthora perniciosa) were pruned. Trees without sprout emergency after one month had one of the branches removed to force out new sprouts. Only about $10 \%$ of the plants on the block did not have sprouts, or the presented failed grafting. In those cases, they were not considered for analysis. Organic and chemical fertilization recommended for the management of cupuassu trees were applied, using cattle manure (10 $\mathrm{L} / \mathrm{plant} /$ harvest) and mineral nutrients based on $1.5 \mathrm{~kg}$ of formulation 10-28- 20 per plant/harvest (ALVES; FERREIRA, 2012; ALVES, 2014). The following fertilizers were applied divided into two applications per year during the entire evaluation period: 2 shovels of poultry litter + $2 \mathrm{~kg}$ of formulation 10-28-20 $+50 \mathrm{~g}$ of FTE per plant. 


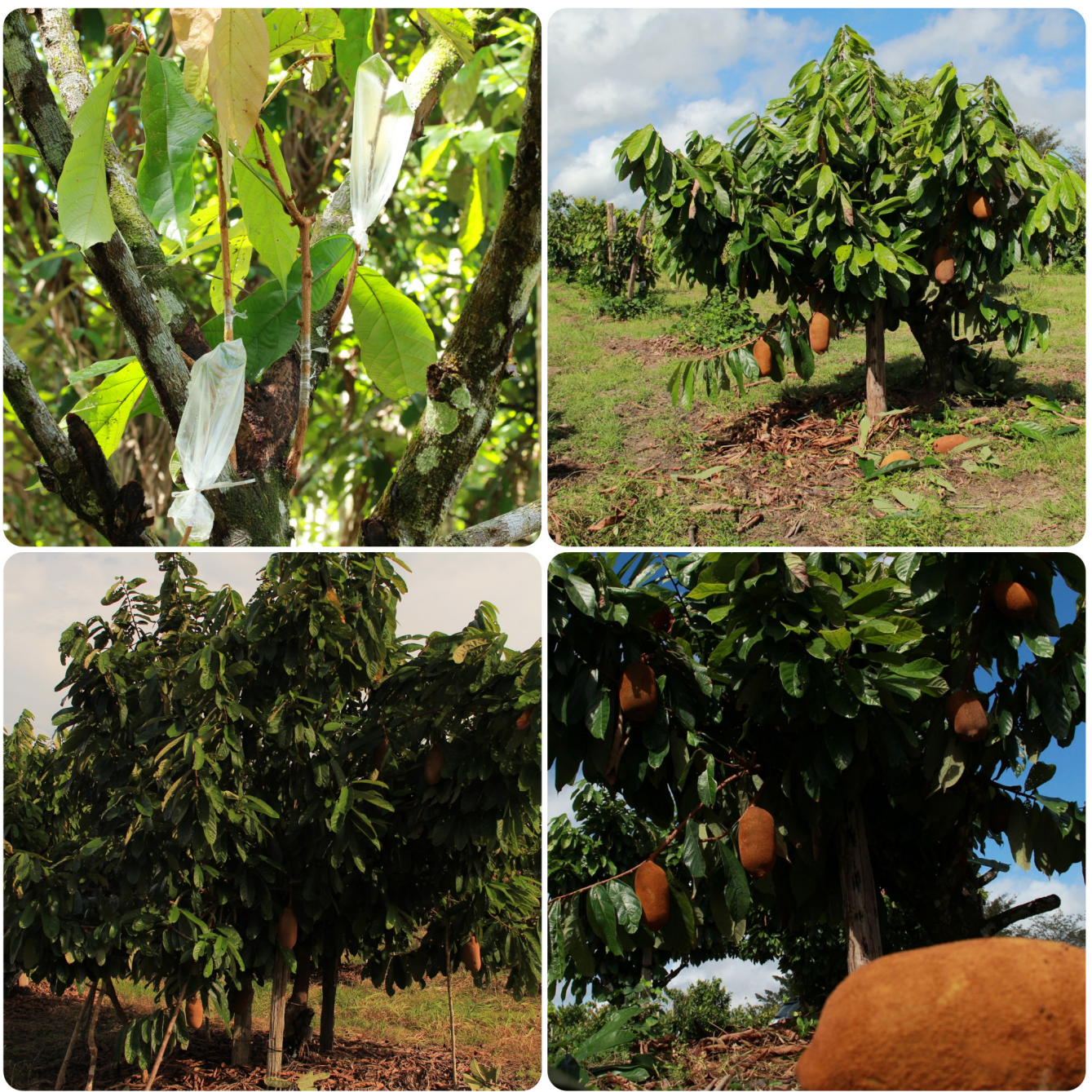

Figure 2 - Images of the field experiment: a) Cupuaçu tree canopy replacement process (grafts made and starting development); b) and c) Plants in initial production stage (new canopy - three and four years); d) Plant during production (new canopy after grafting - six years). Photo: Ronaldo Rosas.

The experiment was designed in completely randomized blocks with 16 treatments, 18 repetitions and one plant per plot. The evaluations were conducted in seven consecutive harvests (2010-2011 to 2016-2017), in which the average number of fruits produced per harvest and the production of fruit, seed and pulp $(\mathrm{kg})$ per harvest were evaluated. The yields were estimated using a sample of 20 fruits per plant in each harvest. Thus, the production of each plant per harvest was obtained by multiplying the average masses of the fruit, seeds and pulp of the samples with the quantity of fruits produced per plant.

A total of 300 plants/ha were considered to estimate pulp and seed productivity. The occurrence of plants attacked by witches' broom was also evaluated. This assessment was based on the visual identification of symptomatic individuals within the same genotype, allowing the ratio between individuals who had some type of symptom and the total number of individuals of the same genotype. These evaluations were carried out concomitantly with the collection of data on fruit production, with three campaigns per harvest, totaling 21 evaluations. The symptom of the disease was identified when at least one branch presented phyllotaxis totally misshapen from a normal branch and, after one month it dried up, remaining in the plant for up to two years (ALVES et al., 2009).

The fruits were characterized ( 90 fruits/clone) using the average values of the following response variables: fruit length and diameter, peel thickness, masses of the fruit, seeds, peel and pulp. The first three variables were measured with a digital caliper, while the others were measured using a semi-analytical balance. The proximate compositions of pulp, seed and peel were estimated, as well as the pulp and seed indices. The proximate compositions were estimated by the ratio between the mass of the components of the fruit and the total mass of the fruit. The pulp and seed indices refer to the estimate of how many fruits would be needed to obtain $1 \mathrm{~kg}$ of pulp and seeds, respectively.

The data collected were initially submitted to the normality test, in which all variables showed normal behavior. The variables related to productivity were subjected to analysis of variance (ANOVA) using the least squares method by the $\mathrm{F}$ test at $5 \%$ probability 
level. The Scott-Knott test was used for grouping the averages at 5\% probability level, using GENES statistical software (CRUZ, 2013). The variables related to the characterization of the fruits were also subjected to analysis of variance, using the Tukey test to compare the averages at $5 \%$ probability level. In order to evaluate the relationship between these variables, Pearson's correlation analysis was performed. All analyzes related to fruit characterizations were performed using SAS software (Statistical Analysis System, 2014).

\section{Results and discussion}

Fruit production showed a low oscillation after the third year of evaluation (Figure 3 ). There was production stability between the third and the seventh harvest (average of 28.2 fruits/plant/harvest, varying from 25.5 to 33.7 fruits/plant/harvest). The production in the first harvest (16.4 fruits/plant/harvest) was higher than that reported in orchards from grafted seedlings or free standing (ALVES et al., 2018a), which often start fruit production in the third year. In the last harvest, the clones produced an average of 33 fruits/plant/harvest, which corresponds to more than $60 \mathrm{~kg}$ of fruits/plant/harvest. However, this production can vary depending on cultural treatments and climatic variations during the flowering and fruiting period (VENTURIERI, 2011). The high performance obtained in the short and medium term of the plants in the present study is related to the grafting used and fertilization. These results corroborate with the premise that adult plants that have their canopy replaced due to the structured root system, being able to reach production stability in less time than any other type of seedling (LEE et al., 2010). Thus, with the treatments, the number of harvests required to be able to select the most productive genotypes is potentially less, without compromising efficiency in identifying the most promising genotypes. Souza et al. (2002) stated that for a selection with $90 \%$ determination, at least eight harvests ought to be evaluated. Therefore, this technology can contribute to reducing the improvement cycle of the cupuassu trees, speeding up the release of new cultivars. The same technique has been used for rubber tree (MARQUES et al., 2003; MORAES; MORAES, 2008) and mango tree (SANTOS et al., 2010).

Clone 44 was the most prolific genotype (average of 43.5 fruits/plant/harvest), with a difference of 30.3 fruits in relation to the control clone (174) and 15.3 fruits for the average of all tested genotypes (Table 2). Moreover, clones 42 and 64 produced an average of 37 fruits/plant/harvest.

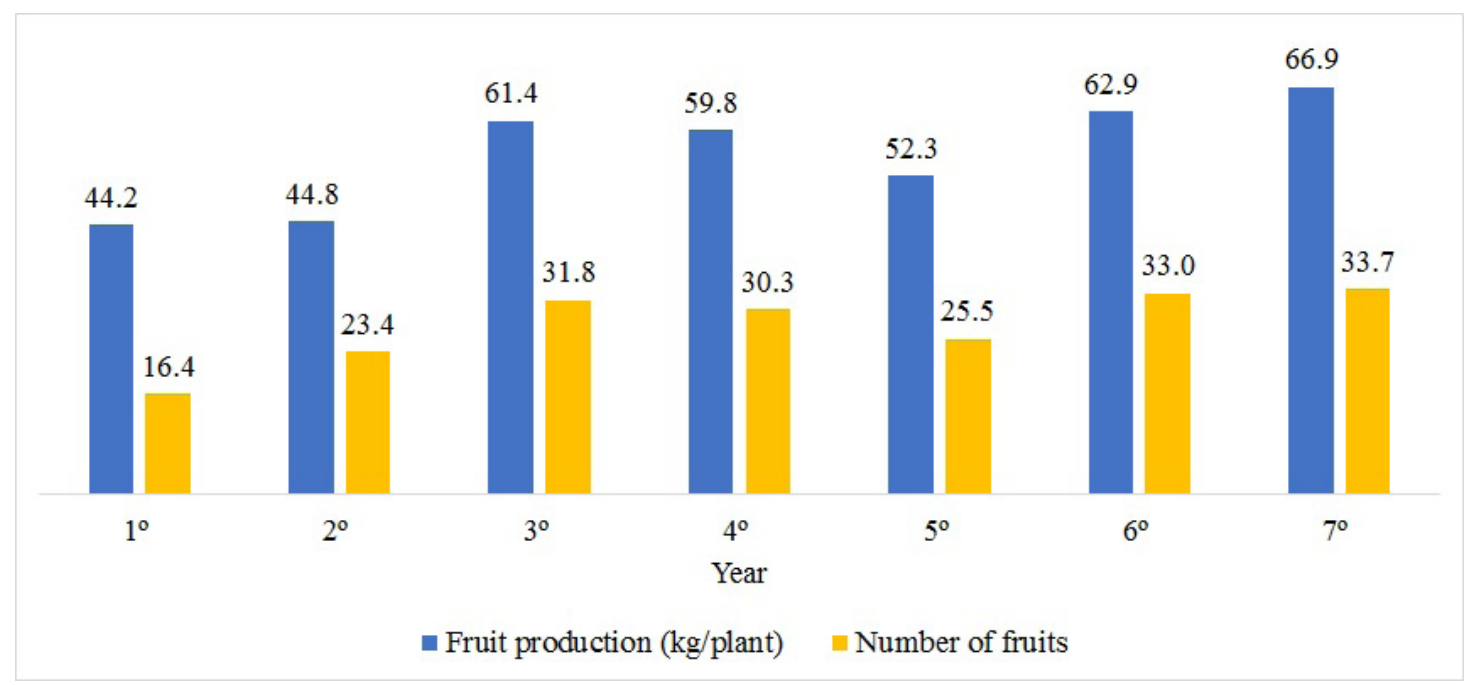

Figure 3 - Evolution of the average of the evaluated clones related to fruit production $(\mathrm{kg})$ and number of fruits per plant per harvest, in a competition trial of cupuassu tree clones, Tomé-Açu, Pará State, Brazil. 
Table 2 - Average number of fruits per plant/harvest (Nf), average fruit (FP), pulp (PP) and seeds (SP) productions per plant/harvest, rate of plants affected by witches' broom (WB), average fruit length (FrL), fruit diameter (FrD), peel thickness (PT), peel mass (PeM), seed mass (SM), pulp mass (PM) and fruit mass (FM), in a competition trial of cupuassu tree clones, in Tomé-Açu, Pará State, Brazil.

\begin{tabular}{|c|c|c|c|c|c|c|c|c|c|c|c|c|}
\hline Clone & $\mathrm{NF}^{*}$ & $\begin{array}{c}\text { FP } \\
(\mathrm{kg})^{*}\end{array}$ & $\begin{array}{c}\text { PP } \\
(\mathrm{kg})^{*}\end{array}$ & $\begin{array}{c}\mathrm{SP} \\
(\mathrm{kg})^{*}\end{array}$ & $\begin{array}{l}\text { WB } \\
(\%)\end{array}$ & $\begin{array}{c}\mathrm{FrL} \\
(\mathrm{mm})^{* *}\end{array}$ & $\begin{array}{c}\text { FrD } \\
(\mathrm{mm})^{* *}\end{array}$ & $\begin{array}{c}\text { PT } \\
(\mathrm{mm})^{* *}\end{array}$ & $\begin{array}{l}\text { PeM } \\
(\mathrm{g})^{* *}\end{array}$ & $\begin{array}{l}\text { SM } \\
(\mathrm{g})^{* *}\end{array}$ & $\begin{array}{l}\text { PM } \\
(\mathrm{g})^{* *}\end{array}$ & $\begin{array}{l}\text { FM } \\
(\mathrm{g})^{* *}\end{array}$ \\
\hline 32 & 4.4e & e & c & $6.7 \mathrm{~b}$ & 0 & $235.5 \mathrm{bc}$ & $125.5 \mathrm{~b}$ & $\mathrm{~b}$ & $\mathrm{~b}$ & $b$ & c & $1800.4 b c$ \\
\hline 42 & $37.4 \mathrm{~b}$ & $6.9 \mathrm{~b}$ & $23.2 \mathrm{~b}$ & $9.6 \mathrm{a}$ & 0 & $4.5 \mathrm{bc}$ & $b$ & $9.7 \mathrm{ab}$ & $a b$ & $258.4 \mathrm{ab}$ & $643.1 \mathrm{bc}$ & $1829.4 \mathrm{bc}$ \\
\hline 44 & $43.5 \mathrm{a}$ & $9.3 \mathrm{~b}$ & $20.6 \mathrm{~b}$ & $9 a$ & 0 & $0.8 \mathrm{bc}$ & 12 & $5 \mathrm{~h}$ & $831.0 \mathrm{~b}$ & $236.9 \mathrm{~b}$ & c & $\mathrm{c}$ \\
\hline 46 & $21.7 \mathrm{e}$ & $45.5 \mathrm{e}$ & $15.4 \mathrm{c}$ & $5.9 \mathrm{~b}$ & 12 & $70.0 \mathrm{ab}$ & $130.3 \mathrm{ab}$ & $9.0 \mathrm{~b}$ & $970.5 \mathrm{ab}$ & $277.7 \mathrm{ab}$ & 758.0ab & $a b$ \\
\hline 47 & $0.6 \mathrm{~d}$ & $60 \mathrm{c}$ & $22.5 b$ & $7.5 \mathrm{a}$ & 0 & $72.2 \mathrm{ab}$ & 121.70 & $9.7 \mathrm{ab}$ & 993.0ab & $247.9 \mathrm{ab}$ & 747.3ab & $1996.0 \mathrm{ab}$ \\
\hline 48 & $25.6 \mathrm{e}$ & $3.9 \mathrm{~d}$ & $18.9 \mathrm{c}$ & $6.3 b$ & 0 & $271.0 \mathrm{ab}$ & 150.000 & 8.70 & $1027.4 \mathrm{ab}$ & $247.0 \mathrm{ab}$ & $766.1 \mathrm{ab}$ & $2063.9 \mathrm{ab}$ \\
\hline 51 & $5.9 \mathrm{~d}$ & $0.9 \mathrm{~d}$ & $16.1 \mathrm{c}$ & $6.7 b$ & 6 & .00 & $\mid 122.10$ & 0.00 & $855.9 \mathrm{~b}$ & $271.0 \mathrm{ab}$ & $649.7 b c$ & 1015.200 \\
\hline 56 & $24.3 \mathrm{e}$ & $.7 \mathrm{~d}$ & $17.5 \mathrm{c}$ & $5.3 \mathrm{c}$ & 6 & $62.6 \mathrm{ab}$ & $126.7 \mathrm{~b}$ & 7.J0 & $936.3 \mathrm{ab}$ & $242.3 \mathrm{ab}$ & 725.8ab & $1935.4 \mathrm{ab}$ \\
\hline 57 & $28.6 \mathrm{~d}$ & $53.6 \mathrm{~d}$ & $19.7 \mathrm{~b}$ & $6.9 \mathrm{~b}$ & 7 & $85.5 \mathrm{a}$ & $121.4 \mathrm{~b}$ & $9.1 \mathrm{~b}$ & $951.4 \mathrm{ab}$ & $241.6 \mathrm{ab}$ & $705.3 b$ & $1927.7 \mathrm{ab}$ \\
\hline 61 & $28 \mathrm{~d}$ & $55.6 \mathrm{~d}$ & $18.4 \mathrm{c}$ & $7.1 \mathrm{~b}$ & 11 & $253.0 \mathrm{bc}$ & $132.0 \mathrm{ab}$ & $10.2 \mathrm{ab}$ & $1035.2 \mathrm{ab}$ & $280.5 \mathrm{ab}$ & $697.9 b$ & $2058.9 \mathrm{ab}$ \\
\hline 62 & $33.8 \mathrm{c}$ & $67.6 \mathrm{~b}$ & $26.8^{\mathrm{a}}$ & $8 \mathrm{a}$ & 83 & $259.3 \mathrm{ab}$ & $130.1 \mathrm{ab}$ & $9.8 \mathrm{ab}$ & 1013.6ab & $227.7 \mathrm{~b}$ & 791.0ab & $2077.3 \mathrm{ab}$ \\
\hline 63 & $29.7 d$ & $57.6 \mathrm{c}$ & $20.5 b$ & $6.4 b$ & 0 & $227.0 \mathrm{c}$ & $134.9 \mathrm{a}$ & $10.7 \mathrm{a}$ & $1036.7 \mathrm{ab}$ & $205.8 \mathrm{~b}$ & $654.1 b c$ & 1944.6ab \\
\hline 64 & $36.8 \mathrm{~b}$ & $79 a$ & $30.5^{\mathrm{a}}$ & $9.7 \mathrm{a}$ & 12 & $268.7 \mathrm{ab}$ & $131.0 \mathrm{ab}$ & $9.8 \mathrm{ab}$ & $1048.6 \mathrm{a}$ & $259.3 \mathrm{ab}$ & $810.0 \mathrm{a}$ & $2131.1 \mathrm{a}$ \\
\hline 174 & $13.2 \mathrm{f}$ & $26.2 \mathrm{f}$ & $8.8 \mathrm{~d}$ & $3.3 \mathrm{c}$ & 11 & $248.3 \mathrm{bc}$ & $127.0 \mathrm{~b}$ & $10.4 \mathrm{ab}$ & $993.7 \mathrm{ab}$ & $245.9 \mathrm{ab}$ & $622.8 b c$ & $1876.1 \mathrm{~b}$ \\
\hline 215 & $23.7 \mathrm{e}$ & $46.1 \mathrm{e}$ & $15.1 \mathrm{c}$ & $6.7 \mathrm{~b}$ & 10 & $.0 \mathrm{ab}$ & 0 & U & 824 & $282.2 \mathrm{a}$ & 641 & $1957.0 \mathrm{ab}$ \\
\hline 1074 & $23 \mathrm{e}$ & $41.3 \mathrm{e}$ & $13.1 \mathrm{~d}$ & $5 c$ & 78 & $235.8 \mathrm{bc}$ & $130.5 \mathrm{ab}$ & $8.7 \mathrm{~b}$ & $873.8 \mathrm{~b}$ & $271.6 \mathrm{ab}$ & $728.2 \mathrm{ab}$ & $1929.7 \mathrm{ab}$ \\
\hline Average & 28.2 & 53.9 & 18.9 & 6.9 & & 255.6 & 127.5 & 9.6 & 956.1 & 252.9 & 691.5 & 1938.8 \\
\hline CV (\%) & 18.2 & 18.7 & 21.5 & 21.8 & & 6.6 & 3.0 & 7.4 & 11.0 & 11.3 & 8.9 & 8.1 \\
\hline
\end{tabular}

* Averages followed by the same letter do not differ from each other at $5 \%$ probability level by the Scott-Knott test.

** Averages followed by the same letter do not differ from each other at $5 \%$ probability level by the Tukey test.

Clone 64 presented the highest fruit production value, with $79 \mathrm{~kg}$ of fruit/plant/harvest. This clone has primary clone 220 as one of its parents, which also provided good production for clone 62 , in which, together with clones 42 and 44, occupied the second group of the most productive clones. The production of clone 64 is relevant, since it represents a difference of $25 \mathrm{~kg}$ in relation to the test average, and $52.7 \mathrm{~kg}$ of clone 174 used as a control (Table 2). Clone 174 is a primary clone, which has good resistance to some diseases that attack cupuaçu trees, such as witches' broom (BENCHIMOL, 2009) and the fungus Lasiodiplodia theobromae (ALVES et al., 2018b).

The complete sibling clones 64 and 62 originated from the cross $220 \times 185$ were the ones that presented the highest pulp yields, with an average productivity of $8.5 \mathrm{t} \mathrm{pulp} / \mathrm{ha} /$ harvest. This productivity is well above the controls 174 (BRS Coari), 215 (BRS Manacapuru) and 1074 (Table 2). In comparative terms, BRS Carimbó presents pulp productivity $50 \%$ lower (ALVES; FERREIRA, 2012).

Seeds, which until recently were discarded by the agribusiness, now have importance, being used to remove butter used in the pharmaceutical and cosmetics industry (FRAIFE-FILHO et al., 2009). They are still raw material for the production of cupulate, an important technology to make cupuaçu cultivation feasible (GENOVESE; LANNES, 2009). Thus, it is important to identifying genotypes with good pulp and seed yields. In the present study, clones 42, 44, 47, 62 and 64 stood out (Table 2). The average productivity of these five genotypes exceeded $3.8 \mathrm{t}$ fresh seeds/ha/harvest. Moreover, clones $32,46,48$, $51,57,61,63$ and 215 produced an average of $2 t$ of fresh seeds/ha/harvest. BRS Carimbó has a productivity of fresh seeds of $1.5 \mathrm{t} / \mathrm{ha}$ (ALVES; FERREIRA, 2012). Therefore, to start a new line of research looking for genotypes with higher seed yields, this set of clones should be considered.

Plant evaluation for resistance to M. perniciosa was carried out in the field, without human interference so that the horizontal resistance mechanisms could act freely. The effectiveness of this methodology has been previously proven (ALVES et al., 2009). The plants were exposed to the action of the pathogen in the field for 10 years, long enough for the susceptible genotypes to show symptoms of the disease in the branches (witches' brooms). Since these 
witches' brooms were not removed from the trees, the source of the inoculum grew. Of the 16 studied genotypes, $37.5 \%$ showed complete resistance to witches' broom (32, $42,44,47,48$ and 63), in which no plants with symptoms of the disease were registered during the experimental period. This is probably due to the ancestry of these clones, which come from the crossing involving clones 174 and 186. These two parental genotypes are, respectively, BRS Coari and BRS Codajás, two of the four clones launched in 2002 by Embrapa Amazônia Oriental. Souza (2007) pointed out that the high cost of witches' broom control is one of the major drawbacks for the production of cupuassu tress. Therefore, the identification, obtaining and use of genotypes that are proven to be resistant to diseases is the most efficient method to decrease production costs, increasing the profit margin of the producer, in addition to avoiding the imbalance and pollution of the environment with the use of chemical products (BORÉM et al., 2017). Of the ten other clones, eight presented low levels of attack (approximately 10\% of the affected plants) and expressed their productive capacity (Table 2). Only clones 62 and 1074 were highly susceptible to the disease.

The average length of the fruits was $255.6 \mathrm{~mm}$, in which the fruit of clone 57 was the longest, not differing from fruits of other eight genotypes (Table 2). Clone 63 showed the lowest average $(227.0 \mathrm{~mm})$. However, for the fruit diameter, the result was the opposite: clones 63 and 61 had the highest averages. Clone 57 presented the smallest diameter, along with nine other genotypes. The general average of this variable was $127.5 \mathrm{~mm}$. In the selection of cupuaçu trees, priority should be given to plants that have fruits with an adequate length/diameter ratio. The shape of the fruits can influence their mass, number of seeds and pulp yield (ALEXANDRE et al., 2015).

As for the thickness of the fruit peel, the average was $9.8 \mathrm{~mm}$. Clone 63 presented the highest averages, followed by 174 and six other clones (Table 2). It is worth mentioning that clone 174 is one of the parents of clone 63 . Probably, the coarse-skinned characteristic of clone 63 was inherited from this parent. Cocoa trees that produce fruits with thicker skins tend to be more resistant to brown rot (NYADANU et al., 2011). In cupuassu trees, when ripe, the fruit detaches from the plant and falls to the ground, with the risk of cracking, depending on the thickness of the skin. On the other hand, for genetic improvement, fruits with thin skin are more interesting, as was the case with clones 44, 46, 48, 51, 56, 57, 215 and 1074, which have high pulp and seed yields.

As for the peel thickness related to mass, the most interesting clones were those with the lowest mass: 44, 51 and 1074. As for the pulp mass, clone 64 was the highlight with an average of $810.0 \mathrm{~g}$ (Table 2). This characteristic reflects the main commercial product of cupuassu to date, since the amount of pulp produced by the fruit is one of the main characteristics desired by the producer (LIMA,
2013). As for the fruit mass, clone 64 stood out when compared with the other evaluated genotypes. This clone showed interesting characteristics related to the fruit mass and pulp yield. Therefore, it should be recommended to producers, as well as, for integration into the breeding program. As for the average seed mass, clone 215 showed the highest value. This clone is of interest to those producers who aim to produce almonds, whether for the food industry (cupulate) or for the cosmetic-pharmaceutical industry.

The fruits evaluated in the present study showed average values higher than those obtained by Alcoforado et al. (2019) for the average of the characteristics FrL (223.6 mm), FrD (106 mm), PT (6.7 mm), PeM (943.6 g), SM (156.9 g), PP (384, $4 \mathrm{~g})$ and FM (943.6 g). A similar situation was repeated when they were compared with the data obtained by Costa et al. (1997) and Maia et al. (2011). The latter carried out the selection of clones based on production characters and also those of interest to the agribusiness. The average values of the variables were lower, probably due to the genotypic differences and the improvement stages of the two programs.

Pearson's correlations between fruit variables (Table 3 ) revealed that the main economic characteristics, fruit mass and pulp mass, were highly correlated. This indicated that the selection for one characteristic would automatically lead to the improvement of the second. The size of the fruit itself, especially the diameter was indicative of heavier fruit and, consequently, with higher pulp yield. Similar behavior was observed in Alcoforado et al. (2019) for the same variables. However, heavier fruits will not necessarily have a high seed yield. This last variable showed no correlation with any other, except for a negative correlation with peel thickness, indicating that fruits with a thinner peel will tend to produce heavier seeds. 
Table 3. Correlation matrix between pairs of variables for fruit length (FrL), fruit diameter (FrD), peel thickness (PT), peel mass (PeM), seed mass (SM), pulp mass (PM) and fruit mass (FM) in a competition trial of cupuassu tree clones, in Tomé-Açu, Pará State, Brazil.

$\begin{array}{ccccccc} & \text { FrL } & \text { FrD } & \text { PT } & \text { PeM } & \text { SM } & \text { PM } \\ \text { FrD } & -0.25 & & & & & \\ \text { PT } & -0.46 & 0.46^{*} & & & & \\ \text { PeM } & 0.30 & 0.70^{* *} & 0.54^{*} & & & \\ \text { SM } & 0.24 & -0.19 & -0.54^{*} & -0.24 & & \\ \text { PM } & 0.55^{*} & 0.54^{*} & -0.20 & 0.61 * * & 0.08 & \\ \text { FM } & 0.51^{*} & 0.64^{* *} & 0.02 & 0.82^{* *} & 0.14 & 0.9 * * \\ * \mathrm{P}<0.05 ; * * \mathrm{P}<0.01 . & & & & \end{array}$

Other interesting characteristics for characterizing and evaluating cupuassu tree genotypes refer to the proximate composition of the fruit (Table 4). It was observed that half of the fruit consists of the peel. The pulp yield (35.7\%) and seeds (13.2\%) are also within what was expected for the species (GONDIM et al., 2001). Some clones, such as clone 56 and clone 62, showed higher pulp yield similar to BRS Carimbó (ALVES;
FERREIRA, 2012). According to Alves and Ferreira (2012), the seed yield of BRS Carimbó is approximately $13 \%$, which is similar to the value obtained in the present study. However, clones 51 and 215 (control) showed values around $15 \%$. Clones 51 and 46, which also showed high seed yield (14\%) are descendants (progenies) of primary clone 215 (Table 1). This result indicates that clone 215 might be a good supplier of genes to improve the seed yield of cupuassu fruits.

Table 4 - Average yield characteristics of cupuaçu fruits: percentage of peel, percentage of pulp, percentage of seeds, pulp index and seed in a competition trial of cupuassu tree clones, in Tomé-Açu, Pará State, Brazil.

\begin{tabular}{cccccc}
\hline Clone & $\begin{array}{c}\text { Percentage of peel } \\
(\%)\end{array}$ & $\begin{array}{c}\text { Percentage of pulp } \\
(\%)\end{array}$ & $\begin{array}{c}\text { Percentage of seeds } \\
(\%)\end{array}$ & $\begin{array}{c}\text { Pulp index } \\
\text { (Fruits/kg of pulp) }\end{array}$ & $\begin{array}{c}\text { Seed index } \\
\text { (Fruits/kg of seeds) }\end{array}$ \\
32 & 51.4 & 33.3 & 14.6 & 1.7 & 3.9 \\
42 & 48.1 & 35.5 & 14.4 & 1.6 & 3.9 \\
44 & 50.3 & 33.0 & 14.5 & 1.9 & 4.3 \\
46 & 47.6 & 37.1 & 14.0 & 1.3 & 3.5 \\
47 & 49.0 & 37.7 & 12.6 & 1.4 & 4.0 \\
48 & 49.2 & 37.5 & 12.4 & 1.3 & 4.1 \\
51 & 47.8 & 35.6 & 15.0 & 1.5 & 3.6 \\
56 & 48.0 & 38.2 & 12.3 & 1.3 & 4.0 \\
57 & 49.1 & 35.9 & 12.6 & 1.4 & 4.1 \\
61 & 50.9 & 35.0 & 13.7 & 1.4 & 3.7 \\
62 & 49.1 & 38.1 & 11.2 & 1.3 & 4.3 \\
63 & 53.7 & 33.2 & 10.6 & 1.5 & 4.8 \\
64 & 48.6 & 37.3 & 11.9 & 1.3 & 3.9 \\
174 & 53.7 & 32.4 & 12.2 & 1.6 & 4.2 \\
215 & 48.3 & 34.5 & 15.1 & 1.5 & 3.4 \\
1074 & 44.1 & 36.3 & 14.1 & 1.5 & 3.8 \\
Average & 49.3 & 35.7 & 13.2 & 1.5 & 4.0 \\
\hline \hline
\end{tabular}




\section{Conclusions}

The over grafting technique can be used to reduce the time needed for evaluations of cupuassu clones, reducing the selection cycle in genetic breeding programs for the species.

Clones 32, 42, 44, 46, 47, 61 were selected based on production data, disease resistance, fruit characteristics and, especially, on the ancestry of parents as distinct sources of resistance to witches' broom. Clones 62, 63 and 64 can be used in genetic breeding programs for cupuaçu.

Clones 32, 42, 46, 61 and 64 should be made available to producers to replace canopy of unproductive plants.

\section{References}

ALCOFORADO, A.T.W.; PEDROZO, C.A.; MAYER, M.M.; LIMA-PRIMO, H.E.S. Repeatability of morphoagronomic characters of Theobroma grandiflorum fruits. Revista Brasileira de Fruticultura, Jaboticabal, v.41, n.2, p.e-142, 2019. Disponível em: https://www.scielo.br/scielo.php?pid=S010029452019000200801\&script $=$ sci arttext. Acesso em: 27 maio 2020 .

ALEXANDRE, R.S.; CHAGAS, K.; MARQUES, H.I.P.; COSTA, P.R.; CARDOSO FILHO, J. Caracterização de frutos de clones de cacaueiros na região litorânea de São Mateus, ES. Revista Brasileira de Engenharia Agrícola e Ambiental, Campina Grande, v.19, n.8, p.785-790, 2015. Disponível em: https://www.scielo.br/scielo. php?pid $=$ S1415-43662015000800785\& script $=$ sci arttext. Acesso: em 27 maio 2020

ALVES, R.M.; RESENDE, M.D.V.; BANDEIRA, B.S.; PINHEIRO, T.M.; FARIAS, D.C.R. Evolução da vassoura-de-bruxa e avaliação da resistência em progênies de cupuaçuzeiro. Revista Brasileira de Fruticultura, Jaboticabal, v.31, n.4, p.1022-1032, 2009. Disponível em: https://www.scielo.br/scielo.php?pid=S010029452009000400015\&script=sci_arttext. Acesso em: 27 maio 2020 .

ALVES, R.M.; FERREIRA, F.N. BRS Carimbó: nova cultivar de cupuaçuzeiro da Embrapa Amazônia Oriental. Belém: Embrapa Amazônia Oriental, 2012. 8 p.

ALVES, R.M. Substituição de copa do cupuaçuzeiro. Belém: Embrapa Amazônia Oriental, 2014. 34p.
ALVES, R.M.; BASTOS, A.J.R.; CHAVES, S.F.S.; FERNANDES, J.R.Q. Spondias mombin and Theobroma grandiflorum in agroforestry system: productivity implications. Revista Brasileira de Fruticultura, Jaboticabal, v.40, n.6, 2018a. Disponível em: https://www.scielo.br/scielo.php?pid=S010029452018000600703\&script $=$ sci arttext. Acesso em: 27 maio 2020 .

ALVES, R.M; BENCHIMOL, R.L.; OLIVEIRA, R.P.; CHAVES, S.F.S. Resistência de genótipos de cupuaçuzeiro a Lasiodiplodia theobromae. Belém: Embrapa Amazônia Oriental, 2018b. 19 p.

BENCHIMOL, R.L. Manejo de doenças fúngicas do cupuaçuzeiro. In: SIMPÓSIO SOBRE MANEJO DE PRAGAS, 1., 2009, Belém. Anais [...]. Belém: Embrapa Amazônia Oriental, 2009.

BOLFE, E.L.; BATISTELLA, M. Análise florística e estrutural de sistemas silviagrícolas em ToméAçu, Pará. Pesquisa Agropecuária Brasileira, Brasília, v.46, n.10, p.1139-1147, 2011. Disponível em: https://www.scielo.br/scielo.php?pid=S0100204X2011001000004\&script=sci arttext. Acesso em: 27 maio 2020 .

BORÉM, A.; MIRANDA, G.V.; FRITSCHE NETO, R. Melhoramento de plantas. Viçosa: Editora UFV, 2017. $543 \mathrm{p}$.

BORGES, S.F.; PIRES, P.V.; SAMPAIO, R.M.; VÉLEZ, H.A.V. Estudo do comportamento reológico e estabilidade da polpa de cupuaçu (Theobroma grandiflorum). Revista Brasileira de Iniciação Científica, Itapetininga, v.4, n.6, p.61-65, 2017. Disponível em: https://periodicos.itp.ifsp. edu.br/index.php/IC/article/view/1023. Acesso em: 27 maio 2020.

CHASE, M.C.; BYNG, J.W; CHRITENHUSZ, M.J.M.; FAY, M.F.; JUDD, W.S.; MABBERLEY, D.J.; SENNIKOV, A.N.; SOLTIS, D.E.; SOLTIS, P.S; STEVENS, P.F. An update of the Angiosperm phylogeny group classification for the orders and families of flowering plants: APG IV. Botanical Journal of the Linnean Society, London, v.181, n.1, p.1-20, 2016. Disponível em: https://academic. oup.com/botlinnean/article/181/1/1/2416499.Acesso em: 27 maio 2020 .

COMIOTTO, A; FACHINELLO, J.C.; HOFFMANN, A.; MACHADO, N.P.; GALARÇA, S.P.; BETEMPS, D.L. Vigor, floração, produção e qualidade de pêssegos 'Chimarrita' e 'Maciel' em função de diferentes portaenxertos. Ciência Rural, Santa Maria, v.42, n.5, 788794, 2012. Disponível em: https://www.scielo.br/scielo. php?pid $=$ S0103-84782012000500005\&script $=$ sci arttext. Acesso em: 27 maio 2020. 
COSTA, J.G.; LEDO, A.S.; OLIVEIRA, M.N. Estimativas de repetibilidade de características de frutos de cupuaçuzeiro no Estado do Acre. Revista Brasileira de Fruticultura, Jaboticabal, v.19, n.3, p.313-318, 1997. Disponível em: https://www.alice.cnptia.embrapa.br/ handle/doc/492658. Acesso em: 27 maio 2020.

CRUZ, C.D. GENES - a software package for analysis in experimental statistics and quantitative genetics. Acta Scientiarum Agronomy, Maringá, v.35, n.3, p.271276, 2013. Disponível em: https://www.scielo.br/scielo. php?pid=S1807-86212013000300001\&script=sci_arttext. Acesso em: 27 maio 2020.

FERNANDES, P.D.; BRITO, M.E.B.; GHEYI, H.R.; SOARES FILHO, W.S.; MELO, A.S.; CARNEIRO, P.T. Crescimento de híbridos e variedades porta-enxerto de citros sob salinidade. Acta Scientiarum Agronomy, Maringá, v.33, n.2, p.259-267, 2011. Disponível em: https://www.scielo.br/scielo.php?pid=S1807$\underline{86212011000200010 \& s c r i p t=s c i \_a r t t e x t}$. Acesso em: 27 maio 2020.

FRAIFE-FILHO, G.A.; PINTO, W.S.; DANTAS, J.L.L. Cupuaçu. In: SANTOS-SEREJO, J.A.; DANTAS, J.L.L.; SAMPAIO, C.V.; COELHO, Y.S. Fruticultura tropical: espécies regionais e exóticas. Brasília (DF): Embrapa Informação Tecnológica, 2009. p.173-184.

FRANZON, R.C.; GONÇALVES, R.S.; ANTUNES, L.E.C.; RASEIRA, M.C.B. Propagação vegetativa de genótipos de pitangueira (Eugenia uniflora L.) do sul do Brasil por enxertia de garfagem. Revista Brasileira de Fruticultura, Jaboticabal, v.32, n.1, p.262-267, 2010. Disponível em: https://www.scielo.br/scielo. php?pid $=$ S0100-29452010005000003\&script $=$ sci arttext. Acesso em: 27 maio 2020,

GENOVESE, M.I.; LANNES, S.C.S.Comparison of total phenolic content and antiradical capacity of powders and" chocolates" from cocoa and cupuassu. Food Science and Technology, Campinas, v.29, n.4, p.810814, 2009. Disponível em: https://www.scielo.br/scielo. php?pid=S0101-20612009000400017\&script $=$ sci_arttext. Acesso em: 27 maio 2020.

GONDIM, T.M.S.; THOMAZINI, M.J.; CAVALCANTE, M.J.B.; SOUZA, J.M.L. Aspectos da produção de cupuaçu. Rio Branco: Embrapa Acre, 2001. 46p.

GONÇALVES, A.E.S.S.; LAJOLO, F.M.; GENOVESE, M.I. Chemical composition and antioxidant/antidiabetic potential of Brazilian native fruits and commercial frozen pulps. Journal of Agricultural and Food Chemistry, Wsahignton, v.58, n.8, p.4666-4674, 2010. Disponível em: https://pubmed.ncbi.nlm.nih.gov/20337450/. Acesso em: 27 maio 2020.
GONÇALVES, M.V.V.A.; SILVA, J.P.L.; MATHIAS, S.P.; ROSENTHAL, A.; CALADO, V.M.A. Caracterização físico-química e reológicas da polpa de Cupuaçu congelada (Theobroma grandiflorum). Exatas \& Engenharia, Campos dos Goytacazes, v.3, n.7, p.46-53, 2013. Disponível em: https://www.alice.cnptia.embrapa. br/handle/doc/996442. Acesso em: 27 maio 2020.

LEE, J.; KUBOTA, C.; TSAO, S.J.; BIE, Z.; ECHEVERRIA, P.H.; MORRA, L.; ODA, M. Current status of vegetable grafting: Diffusion, grafting techniques, automation. Scientia Horticulturae, Wageningen, v.127, n.2, p.93-105, 2010. Disponível em: https://www.sciencedirect.com/science/ article/pii/S0304423810003699? casa token=E9 S9941XFwAAAAA:dFzEHAAKifGICEpskq6-RNgIX pjfx8EgwrzvdHxobhvx6VOaMxim9aOOjiG272csz0 8F0-QKzd5e. Acesso em: 27 maio 2020.

LIMA, H.E.; SANTOS, V.A.; CHAGAS, E.A.; RODRIGUEZ, C.A.; ARAÚJO, M.C.R. Severidade da vassoura de bruxa em genótipos de cupuaçuzeiro cultivados em sistema agroflorestal e produção de genótipos tolerantes à doença. Cadernos de Agroecologia, Recife, v.8, n.2, 2013. Disponível em: https://www.alice.cnptia. embrapa.br/bitstream/doc/980740/1/14378623891PB.pdf. Acesso em: 27 maio 2020.

MAIA, M.C.C.; RESENDE, M.D.V.; OLIVEIRA, L.C.; ÁLVARES, V.S.; MACIEL, V.T.; LIMA, A.C. Seleção de clones experimentais de cupuaçu para características agroindustriais via modelos mistos. Revista Agro@ mbiente On-line, Boa Vista, v.5, n.1, p.35-43, 2011. Disponível em: https://revista.ufrr.br/agroambiente/ article/view/388. Acesso em: 27 maio 2020.

MARQUES, J.R.B.; MONTEIRO, W.R.; MORAES, V.H.F. Ampliação dos recursos genéticos de seringueira (Hevea spp.) pela introdução de novos clones-copa resistentes ao mal-das-folhas (Microcyclus ulei). Agrotrópica, Itabuna, v.15, n.2, p.121-126, 2003. Disponível em: https:// www.alice.cnptia.embrapa.br/bitstream/doc/1109999/1/ AMPLIACAODOSRECURSOSGENETICOS ....pdf. Acesso em: 27 maio 2020.

MORAES, V.H.F.; MORAES, L.A.C. Desempenho de clones de copa de seringueira resistentes ao maldas-folhas. Pesquisa Agropecuária Brasileira, Brasília, DF, v.43, n.11, p.1495-1500, 2008. Disponível em: http://www.scielo.br/scielo.php?pid=S0100204X2008001100007\&script=sci arttext\&tlng $=$ pt.Acesso em: 27 maio 2020. 
NYADANU, D.; ASSUAH, M.K.; ADOMAKO, B.; ASIAMA, Y.O.; ADU-AMPOMAH, Y. Thickness of the cocoa pod husk and its moisture content as resistance factors to Phytophthora pod rot. International Journal of Agricultural Research, New York, v.6, p.310-322, 2011. Disponível em: https://scialert.net/ fulltextmobile/?doi=ijar.2011.310.322. Acesso em: 27 maio 2020 .

OLIVEIRA, T.B.; GENOVESE, M.I. Chemical composition of cupuassu (Theobroma grandiflorum) and cocoa (Theobroma cacao) liquors and their effects on streptozotocin-induced diabetic rats. Food Research International, New York, v.51, n.2, p.929-935, 2013. Disponível em: https://www.sciencedirect.com/science/ article/pii/S0963996913001129. Acesso em: 27 maio 2020 .

SANTOS, E.C.S.; SOUZA, R.C.R.; SEYE, O.; LAU, J.; FREITAS, K.T. Aproveitamento da casca do cupuaçuzeiro para a produção de energia. In: ENCONTRO DE ENERGIA NO MEIO RURAL, 5., 2004, Campinas. Anais [...]. Manaus: CDEAM, 2004. Disponível em: http:// www.proceedings.scielo.br/scielo.php?pid=MSC000000 $\underline{0022004000100015 \& \text { script }=\text { sci arttext } \& \text { tlng }=\text { pt. Acesso }}$ em: 27 maio 2020 .

SANTOS, C.A.F.; LIMA FILHO, J.M.P.; LIMA NETO, F.P. Estratégias para o desenvolvimento de novas cultivares de mangueira para o semiárido brasileiro. Revista Brasileira de Fruticultura, Jaboticabal, v.32, n.2, p.493497, 2010. Disponível em: https:/www.scielo.br/scielo. php?pid=S0100-29452010005000057\&script=sci_arttext. Acesso em: 27 maio 2020.
SILVA, M.G.M.; VIANA, A.P. Alternativas de seleção em população de maracujazeiro-azedo sob seleção recorrente intrapopulacional. Revista Brasileira de Fruticultura, Jaboticabal, v.34, n.2, p.525-531, 2012. Disponível em: https://www.scielo.br/scielo.php?pid=S0100$29452012000200026 \&$ script $=$ sci arttext\&tlng $=$ pt. Acesso em: 27 maio 2020 .

SIRTOLI, L.F.; CERQUEIRA, R.C.; RODRIGUES, J.D.; GOTO, R.; BRAGA, C.L. Enxertia no desenvolvimento e qualidade de frutos de tomateiro sob diferentes porta-enxertos em cultivo protegido. Scientia Agraria Paranaensis, Marechal Candido Rondon, v.10, n.3, p.15-22, 2011. Disponível em: https://repositorio.unesp. br/handle/11449/140380. Acesso em: 27 maio 2020.

SOUZA, A.G.C.; RESENDE, M.D.V.; SILVA, S.E.L.; SOUSA, N.R. The cupuaçu genetic improvement program at Embrapa Amazônia Ocidental. Crop Breeding and Applied Biotechnology, Londrina, v.2, n.3, 2002. Disponível em: http:/www.sbmp.org.br/cbab/siscbab/ uploads/c8128f42-5401-6c3a.pdf. Acesso em: 27 maio 2020.

SOUZA, A.G.C. Boas práticas agrícolas da cultura do cupuaçuzeiro. Manaus: Embrapa Amazônia Ocidental, 2007. 56p.

VENTURIERI, G.A. Flowering levels, harvest season and yields of cupuassu (Theobroma grandiflorum). Acta Amazonica, Manaus, v.41, n.1, 2011. Disponível em: https://www.scielo.br/scielo.php?pid=S004459672011000100017\&script $=$ sci arttext. Acesso em: 27 maio 2020. 